\author{
Joseph P. Garske \\ (Chairman of The Global Conversation)
}

\title{
Finding the Origin of a modern, secular, and materialistic World ${ }^{1}$
}

\begin{abstract}
In the global age the modern Western, secular, and material way of understanding human existence is generally accepted to provide the norm by which every alternative view is evaluated. It is the standard against which all other ways of thinking are judged. It is the accepted basis on which entire systems of law, forms of government, methods of education, and a modern way of life is extended across every region and people of the earth.

Viewed historically, however, the fact that such a way of understanding should become the norm is quite ironic. Despite the predominance of this mode of thought in the present age, as far as can be determined, nearly all people who have ever lived on the earth, until very recent times, have lived according to principles and values that not only included the rational and material ways of understanding but combined them with a religious, sacred, or miraculous aspect as well.

In fact, the peoples of the West were once uniformly of this mentality-and many remain so. Moreover, it was not until a great transformation began to take place, beginning around 1600 that the modern secular and materialistic way of understanding came to provide the basic premise for a Western way of life in which religious belief and spirituality survived, but mostly in an instrumental or subordinated role.

The story of how this new Method of understanding--premised on Thought rather than Being, Fact rather than Truth, Empirical and Rational, rather than a fully human way of apprehending--involves three pivotal figures: Francis Bacon, Rene Descartes, and especially, Peter Ramus (Pierre de La Ramee). Following on these men an architecture of the modern mind -what Foucault called an episteme - is coming to predominate among a global population. It is a way of thinking based on some combination of their teachings. To understand how and why this occurred is to understand how and why the sacred or miraculous dimension of human existence lay outside a paradigm that shapes the global age.
\end{abstract}

SUMMARY: 1. The relevant Past - 2. Protest and Print - 3. The ramist Answer - 4. Modern Minds - Two Foundations.

${ }^{1}$ Article peer evaluated. 


\section{1 - The relevant Past}

Events of the sixteenth century may seem remote and unrelated to the present day. But, in fact, there are many parallels between that periodsometimes called the First Globalization--and the unfolding globalization project of today. One similarity is that the transformation undergone at that time was heavily dependent on dramatic technological advances. The innovation of the printing press, for example, had an impact as profound in extent and depth as that of the electronic communication networks in the twenty-first century. What historians call the coming of the book began to shape a modern Western mentality to the same extent that technology of the information age is shaping a postmodern global mentality. (Febvre 1997)(Eisenstein 2012).

However, the parallel between the two eras is not so much the technology itself. Instead, it concerns the question of how that technology has been employed. In the sixteenth century the use of print allowed for the first time widely circulated publications of exactly uniform content. This not only led to an increase in literacy, it also became possible to shape the collective mind across all regions of Christendom. It did so in the same way an immersive atmosphere of electronically transmitted sound and image now makes it possible to shape human awareness among every people in every region of the earth. One reason the tumult of the sixteenth century appears to be so dissimilar and remote from today is because events of that era were expressed in the language of religion, while today they are expressed in a secular and materialistic way. To understand the transition from a religious to a modern structure of mind - what Foucault called an episteme - is to understand a great deal about the convulsive transformation of human understanding in the age of globalization, and what it portends for the future. (Misa 2011)(Cusset 2008)(Rhodes 2000)

\section{2 - Protest and Print}

A turning point of the sixteenth century occurred when John Calvin (15091564) began to lead what historians call the Protestant Reformation, an event that took place across the Christian world from about 1520 to about 1650 . Even though Martin Luther is generally credited with initiating that great transformation, it was Calvin whose impact had the most lasting significance. Although his career is generally recounted in religious terms, his attempt to construct a worldwide movement of Christian governance occurred when the realms of law and religion were inextricably bound 
together. But with his program of Biblical rule he attempted to establish a basis of governance completely different from the old order of pope and emperor, bishop and king, priest and commoner. He also rejected the governing methods of the ancient Greeks and Romans. Instead, he chose to pattern his new Christian Zion on the theocratic legalism of Rabbinic Judaism. It came to be called the Respública Hebraeorum. (Nelson 2010)(Bellomo 1995)

However, the Calvinist version of such a polity bore little resemblance to what had been passed down over centuries by the Rabbis. Instead, it was based on the two theological doctrines: Most basic was the doctrine of human depravity. The logic of the new regime was premised on the innate corruption, the malevolent nature of man-and the consequent need for stern rule. Along with that was the second doctrine of predestination, holding that humanity was divided into two strata, an Elect, chosen of God and a multitude of commoners-and the inevitability that the worthy would preside as ministers and magistrates. The result was an infamous pattern of repressive regimes maintained through the institution of judicial terror.

By the end of the sixteenth century the entire Christian world, once united, was riven by civil and religious warfare. With the breakdown of religious hegemony, its foundational teachings were also in a state of anarchy. In fact, the spectre of torture and punishment for such crimes as apostacy, heresy, and witchcraft became so disruptive that there began a search among certain followers of Calvin for a new episteme. That is (expressed in Latin) a new methodus, a reality or mentality that could replace religiosity as a framework of understanding and would halt the bitter divisiveness of imposed religious belief. (Schochet 2008) (Martines 2006)(Cunaeus 2006)

\section{3 - The ramist Answer}

In this crisis a first potentially viable alternative was put forward by the French professor of law and rhetoric, Peter Ramus (1515-1572) (Pierre de La Ramee). In a legal culture immersed in the beliefs of Christianity the one thing that made an entirely different educative basis of public order possible was the innovation of print. Until about 1500 almost all teaching and learning had been done by oral exchange, dialogue, between teacher and student. In the medieval age when books were hand copied, extremely rare and valuable, a university might attain a high reputation because it possessed a few precious volumes. Even instruction at the 
university might consist of a master reading a text to a classroom of students. Medieval Christendom had been fundamentally a mnemonic culture, with customary teachings of the village transmitted orally and preserved by memorization. But printing made it possible to disseminate precisely identical texts of great length and complexity, especially to institutions of authority and persons of rank. (Caruthers 2008)(Ong 2012)(Yates 2000)

The idea of Ramus was to construct a non-religious framework of ideas within which transactions of governance could be framed. That is, to replace the theological assumptions about the purposes of God, about human destiny, the teachings of the Church that had underlain Western methods of order for a thousand years. The Ramist methodus consisted of an architecture of ideas derived from classical sources that had been the staple of learning in the Latin Christian realm. Especially important were the tenets of the Ars Rhetorica, the highly developed techniques of speech and persuasion. The details of the method he set forth is of limited historical importance because it was a failure and was soon discarded. But the fundamental premise--a structure of assumptions within which to frame human thought--would prove to be astonishingly successful. The basic elements can be understood by contrasting them with what they replaced. (Ong 2005)(Assmann 2011)(Skalnik 2002)

For example, instead of Being as the premise of existence, Ramus set forth the idea that Thought was the decisive manifestation of human existence. Instead of subjective Truth as necessary for human concord, he emphasized the centrality of objective Fact. Instead of reflective Wisdom, he emphasized calculative Knowledge, instead of Memory, he relied on the Text. In matters of Logic he advocated, not the syllogism or dialogue in pursuit of truth, but the use of Logic for purposes of persuasion. In place of the Dialogue, he chose the Lecture. For Ramus, the relevant question regarding his methodus was strictly utilitarian. Its importance was not whether it reflected any version of truth or natural reality, but whether it could bring an end to conflict and conflagration and provide an educative basis of order. In fact, one advantage of his approach was that it did not necessarily contradict the religious or the spiritual. It could exist parallel with such beliefs. Most of all, his was a construction of ideas restricted to the intellectus, the mechanical dimension of the many-faceted human mind. It simply omitted the other more subtle and intuitive levels of human consciousness along with the miraculous dimension of human experience. Those intimations were considered too insubstantial and unreliable for purposes of civic stability. (Bertboud 2020)(Poovey 1998) 
It is important to point out that when Ramus died in 1572 many, perhaps all, the prominent supporters of his approach believed in the spiritual, the miraculous, even in ghosts and devils. This is apparent in the work of his disciple, the French jurist Jean Bodin in his Of Demon-Mania and Sorcerers. Yet, the spiritual dimension, just as the intuitive and subjective dimension of human experience, were viewed as being almost impossible to regulate. The purpose was to set aside these more elusive aspects of human perception, to construct an edifice of fixed ideas within which human affairs could be understood. After his death amid the carnage and bitterness of sectarian conflict there began an urgent search for a new Method. The opinion was widely held that only by this means could order be restored in the new Protestant domains and, with that, overarching authority could finally be wrested from the Universal Church and Empire. (Graves 1912/2017)(Feingold 2001)(Gilbert 1960/2013)

\section{4 - Modern Minds}

Of the many attempts to construct such an approach, such a framework of ideas, there were two famous and notable successes. They came into being almost exactly simultaneously, one in France, the other in Britain. But the two were based on entirely different premises and worked by very different means. One was the Empirical Method set forth by Sir Francis Bacon in England, the other was the Rational Method set forth by Rene Descartes in France. As systems, as approaches to knowing, they worked wholly independently from one another. Yet, when the two epistemologies were examined by the aristocracy of learning across the Christian world, they were soon recognized as viable alternatives to theological teachings, whether Catholic or Protestant. They were thought to provide a mentality suitable for both ruler and ruled - the twin faces of what Foucault called governmentality. (Coquillette 1992)(Foucault 2005)

Sir Francis Bacon (1561-1626) was Lord Chancellor of England, the highest legal official of the monarchy. But he not only understood English law and the politics of rule he was also a polymath of prodigious learning. His Empirical Method was the origin of what came to be called Western Science with its use of experiment and proof. It was based on verifiable experience of the senses to understand the universe in quantifiable, objective, impersonal, and mechanical ways. Importantly, as a way of conceiving reality, his regimen did not necessarily contradict religion, instead it carved out a limited and separate realm of perception. It simply 
made religion unnecessary for purposes of governance. For his innovation Bacon came to be known as the Father of Modern Science. (Kuhn 2012)

René Descartes (1596-1650) attended the Jesuit University at La Fleche, then was trained for the practice of law at Portiers. But when his interests turned to more fundamental questions, he began his philosophical career with a first book, Rule for Direction of the Mind. Later he would become widely famous with his Discourse on Method published in 1637. The Cartesian structure began famously with the simple proposition cogito, ergo sum, "I think, therefore, I am." Extrapolating from this basic assertion he was able to construct an entire system of principles and conclusions that came to be called Rationalism. Like Baconian Science, this new philosophy did not necessarily attack religion. It simply provided a specifically organized realm of thought equipped with plausible and convincing intellectual tools necessary to legitimately govern and a mentality to be governed. For his work Descartes came to be known as the Father of Modern Philosophy. (Tambiah 2006)(Thomas 1997)

These two approaches to understanding were perfectly correlated to the advance of technology. In a profound way the very basis of Western life was becoming change, or what came to be known as Progress. Since time immemorial human beings had lived according to principles and teachings thought to be timeless, ineffable. The doctrines of Christianity were thought to be eternally valid for all peoples and for all of time. But with the new methods the new basis of life was no longer the eternal or transcendent. Instead, it was coming to be based on the ever-changing, ever-progressing advancement of learning, scientific and intellectual. The realm of experimentation opened by Bacon, like the reasonings of Descartes were realms of continuous change and adaptation. The new way of life, like the new regimen of thought and advancing technology would be timely, current, or in the Latin term, modo, or modernus. The modern age was being born with the modern ever-developing Western mind. (Jacob 1997)

\section{5 - Two Foundations}

The seventeenth century saw an effectual end to the wars of law and religion that historians identify with the Protestant Reformation. It also saw the beginning of modern methods of governance with a marked change in the relationship between established religion and constituted authority. It did so under a strong Calvinist and Ramist influence, but the way this occurred on the Continent was different from the way it developed in 
England. Those differences remain important for the global age as the modern Civilian and Anglophone legal traditions converge to form an atmosphere of global law. (Domingo 2010)

On the Continent, the overthrow of the old marriage of Universal Church and Universal Empire took place, symbolically, at least, at the Peace of Westphalia in 1648. It was there, in an atmosphere permeated by Calvinist anthropology and Cartesian Rationalism, that the modern idea of the nation-state was born. This development was also made possible by the new technology of print, especially the feature of moveable type. Books were no longer printed only in Latin. Instead, with the ability to move the alphabetic characters, they could be printed in any language. This made it possible to print law codes, Bibles, and entire literatures in each national language. This gave rise to separate political enclaves-and broke apart the old unity of Latin Christendom. Although the nation-state would not reach its final form for another century, it was invariably based in a text, a printed charter or constitution and a published code of law. (Lesaffer 2009)

Whether this new state took the form of a republic, a commonwealth, or a kingdom, it had territorial supremacy, or sovereignty in that it held exclusive authority over all persons and things within its border. It had a legislative capacity to enact and publish new ordinances and statutes. Finally, it had the right to diplomatic relations with any other state as well as the right to wage war. In terms of independent sovereignty, all legally ordered states, large and small, were recognized as being equal in status. On the Continent, religion continued to be an important unifying influence among the populations. But the general tendency was toward a secularized state. Its educative method would reflect Cartesian abstraction, not theology, but ideology. (Giddens 1991)

Events in England unfolded somewhat differently when a strong Calvinist influence entered the island kingdom in the form of Puritanism. One result was an overthrow of the Monarchy and the establishment of a Puritan Commonwealth; but dissention made it unsustainable. Eventually, the Monarchy was permanently restored during the Glorious Revolution of 1688. It retained many outward features of a highly centralized Norman Kingship, but internally it was unique. Most of all it had an unwritten constitution, was organic in nature, and was founded on three ruling classes, hereditary Royalty and Nobility, along with a fraternal Gentry. Together, they convened in a Parliament that was considered omnicompetent. Most of all, in 1688, the guildsmen of the Common Law courts, who had been among the most ardent Puritans, saw their method of legal practice assimilated to the structure of the Monarchy itself. At the 
same time, their law took on the pretensions of a fully realized legal system, that they now deemed comparable to Continental practice. (Coquillette 1999)(Van Caenegem 1989)

The English approach to governance, however, was unlike the Continental, in that the English adhered to no strict philosophical tradition. Generally, the Europeans attempted to fashion a single ideology of understanding that united both the judicial stratum and the public on the same principles of rationality. By contrast, English rule rested on sharp divisions of class - aggregated wealth, training in manner and speech, as well as a knowledge of intricate law - that marked the fundamental division of British life. At the same time the religion of an Established Church, its rite and ceremony, was the unifying public feature of hierarchical order. On the Continent the typical government would become avowedly secular, the philosopher would become a key figure in the legal culture just as the theologian had been in the past. By contrast, conversations in England would involve less of the philosophical and more of the challenge to reconcile science and religion. Understandings of both the Monarchy and the Common Law were expressed in the language of majesty and faith. (Smith 2009)

\section{SOURCES:}

Assman, Jan 2011: Cultural Memory and Early Civilization: Writing, remembrance, and political imagination, Cambridge University

Bellomo, Manlio 1995: The Common Legal Past of Europe 1000-1800, CUP of America

Bertboud, Jean-Marc 2020: Peter Ramus: Precursor to Descartes against the confessional reformed faith, Zurich Publishing

Caruthers, Mary 2008: A Study of Memory in Medieval Culture, Cambridge University

Coquillette, Daniel 1999) The Anglo-American Legal Heritage, Carolina Academic Press

Coquillette, Daniel 1992: Francis Bacon, Stanford University

Cunaeus, Petrus 2006: The Hebrew Republic, Shalem Press

Cusset, Francois 2008: French Theory: How Foucault, Derrida, Deleuze \& Co. transformed the intellectual life of the United States, University of Minnesota

Domingo, Rafael 2010: The New Global Law, Cambridge University

Eisenstein, Elizabeth 2012: The Printing Revolution in Early Modern Europe, Cambridge University

Febvre, Lucien 1997: The Coming of the Book, Verso 
Feingold, Mordechai 2001: The Influence of Petrus Ramus: Studies in sixteenth and seventeenth century philosophy and sciences, Scwabe \& Company

Foucault, Michael 2005: The Hermeneutics of the Subject: Lectures at the College de France, Palgrave

Giddens, Anthony 1991: Modernity and Self-Identity, Stanford University

Gilbert, Neal 1960/2013: Renaissance Concepts of Method, Facsimile Publishers

Graves, Frank 1912/2017: Peter Ramus and the Educational Reformation of the Sixteenth Century, Facsimile Publishers

Jacob, Margaret 1997: Scientific Culture and the Making of the Industrial West, Oxford University

Kuhn, Thomas 2012: The Structure of Scientific Revolutions, University of Chicago

Lesaffer, Randall 2009: European Legal History, Cambridge University

Martines, Lauro 2006: Fire in the City: Savonarola and the struggle for Renaissance Florence, Oxford University

Misa, Thomas 2011: Leonardo to the Internet: Technology $\mathcal{E}$ culture from the Renaissance to the present, Johns Hopkins University

Nelson, Eric 2010: The Hebrew Republic: Jewish sources and the transformation of European political thought, Harvard University

Ong, Walter 2012: Orality and Literacy, Routledge

Ong, Walter 1983: Ramus: Method and the decay of dialogue, Harvard University

Poovey, Mary 1998: A History of the Modern Fact: Problems of knowledge in the sciences of wealth and society, University of Chicago

Rhodes, Neil 2000: The Renaissance Computer: Knowledge and technology in the first age of print, Routledge

Schochet, Gordon 2008: Political Hebraism: Judaic source in early modern political thought, Shalem Press

Skalnik, James 2002: Ramus and Reform: University and church at the end of the Renaissance, Sixteenth Century Essays \& Studies

Smith, Barbara 2009: Natural Reflections: Human cognition at the nexus of science and religion, Yale University

Tambiah, Stanley 2006: Magic, Science, Religion, and the Scope of Rationality, Cambridge University

Thomas, Keith 1997: Religion and the Decline of Magic, Oxford University

Van Caenegem, R.C. 1989: The Birth of the English Common Law, Cambridge University

Yates, Frances 2000: The Art of memory, Pimlico 